\title{
Erratum to: Estrogen or Estrogen Receptor Agonist Inhibits Lipopolysaccharide Induced Microglial Activation and Death
}

Joshua A. Smith · Arabinda Das • Jonathan T. Butler • Swapan K. Ray $\cdot$ Naren L. Banik

Published online: 18 March 2011

(C) Springer Science+Business Media, LLC 2011

Erratum to: Neurochem Res

DOI 10.1007/s11064-010-0336-7

The funding acknowledgements were not included in the original publication of the article.
The details are provided below,

"This investigation was supported in part by the R01 grants from the NINDS (NS-31622, NS-41088, NS-45967, and NS-57811) and the NIH (C06RRO15455)."

The online version of the original article can be found under doi: 10.1007/s11064-010-0336-7.

J. A. Smith · A. Das · J. T. Butler · N. L. Banik ( $\varangle)$ Department of Neurosciences, Medical University of South Carolina, 96 Jonathan Lucas Street, 310 Clinical Sciences Building, Charleston, SC 29425, USA

e-mail: baniknl@musc.edu

\section{S. K. Ray}

Department of Pathology, Microbiology and Immunology, University of South Carolina School of Medicine, Columbia, SC, USA 